\title{
Cahnite from Fuka, Okayama Prefecture, Japan
}

\author{
Kanako Shiraga*, Isao KuSACHI**, Shoichi Kobayashi*** \\ and Yasushi TAKECHI**** \\ *The Foundation for Environmental Rehabilitation and Redevelopment of \\ Mizushima, Kurashiki 712-8034, Japan \\ **Department of Earth Sciences, Faculty of Education, Okayama \\ University, Okayama 700-8530, Japan \\ ***Division of Earth Sciences, Kurashiki University of Science and \\ the Arts, Kurashiki 712-8505, Japan \\ ****Kurashiki Museum of National History, Kurashiki 710-0046, Japan
}

\begin{abstract}
Cahnite was found in a vein that intruded crystalline limestone in the vicinity of skarns at Fuka, Okayama Prefecture, Japan. This is the first occurrence of cahnite in Japan. It occurs as aggregates of tetrahedral crystals up to $1 \mathrm{~mm}$ long on calcite crystals that grow on cavity walls in the vein, and as anhedral crystals in direct contact with johnbaumite in the vein. The other associate minerals are mainly andradite, arsenopyrite and löllingite. Electron microprobe analyses and ICP-MS give the empirical formula $\mathrm{Ca}_{2.09} \mathrm{~B}_{0.95} \mathrm{As}_{0.93} \mathrm{Si}_{0.06} \mathrm{O}_{3.92}(\mathrm{OH})_{4.08}$ on the basis of $\mathrm{O}=8$. The unit cell parameters in tetragonal system are $a=7.101(1)$ and $c=6.192(1) \AA$. The mineral is optically uniaxial negative with refractive indices $\omega=$ 1.658(1) and $\varepsilon=1.657(1)$. The Vickers microhardness is $413 \mathrm{~kg} \mathrm{~mm}^{-2}$ and the Moh's hardness number is 4.5. The density is $3.13(2) \mathrm{g} \mathrm{cm}^{-3}$. It is likely that cahnite at Fuka was formed as a secondary mineral by a late-hydrothermal alteration of johnbaumite.
\end{abstract}

\section{Introduction}

Cahnite, $\mathrm{Ca}_{2} \mathrm{BAsO}_{4}(\mathrm{OH})_{4}$, is a very rare Ca, B-bearing arsenate hydroxide. The mineral was first recorded by Palache and Bauer (1927) from Franklin, New Jersey, where it occurs as small, well-formed crystals in the cavities of veinlets composed of garnet, axinite, friedelite, barite and calcite. Subsequently, cahnite was described at skarn zones such as the Klodeborg mine, Arendal, Norway (Bugge, 1951) and the Siberian deposit, USSR (Malinko, 1966). At the Klodeborg mine, cahnite occurs in a calcite-marble together with crystals of calcite in dumps, and at the Siberian deposit, the mineral occurs in rocks composed principally of svabite and subordinately of magnetite, sphalerite, garnet and calcite. As another occurrence, Embrey (1960) reported cahnite at Capo di Bove, Rome, Italy, where it is found in a sample of leucite lava in association with phillipsite and chabasite. Helvacı (1984) also reported the mineral in the Emet mine, Turkey. It occurs as very small spher-

K. Shiraga, kabakana@mx1.tamatele.ne.jp

I. Kusachi, kusachi@cc.okayama-u.ac.jp Corresponding author ulites in teruggite nodules, and as a coating on euhedral colemanite crystals in vugs in colemanite nodules.

During a mineralogical survey of the gehlenitespurrite skarns at Fuka, Okayama Prefecture, Japan, cahnite was found in a vein cutting through crystalline limestone. This is the first occurrence of cahnite in Japan. The present paper deals with its mode of occurrence and mineralogical properties.

\section{Occurrence}

At Fuka, arsenic-bearing minerals such as johnbaumite (Kusachi et al., 1996), arsenopyrite and löllingite are known to occur in veins cutting through crystalline limestone in the vicinity of gehlenite-spurrite skarns. Cahnite is also an arsenic-bearing mineral, and was found in the same vein. The width of the vein is approximately $10 \mathrm{~cm}$. The vein is composed mainly of andradite, johnbaumite, arsenopyrite, löllingite and calcite. Other minor minerals are pentahydroborite, cuspidine, native-bismuth, bornite, valleriite, hematite and magnetite. Cahnite occurs as aggregates of tetrahedral crystals up to $1 \mathrm{~mm}$ long on calcite crystals grown 


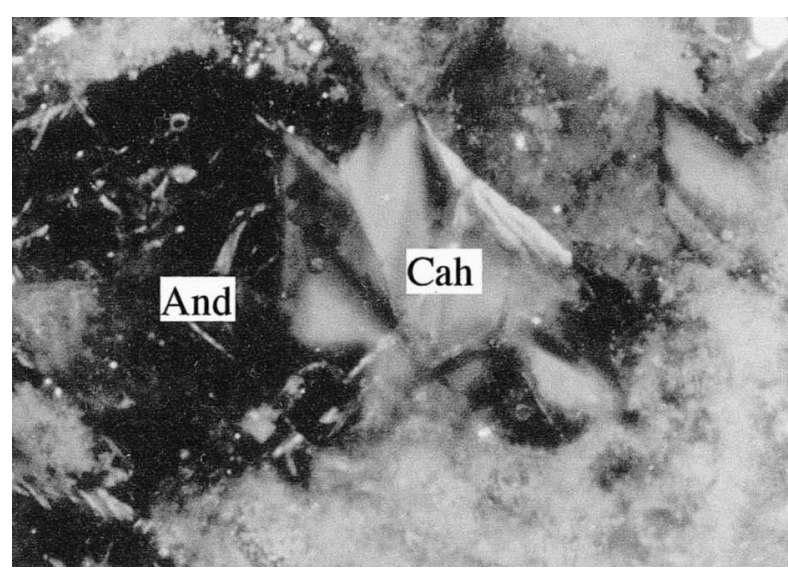

Figure 1. Photomicrograph of cahnite crystals from Fuka. Scale bar indicates $0.1 \mathrm{~mm}$.

Crossed-polarized light. Abbreviations: Cah, cahnite; And, andradite.

on cavity walls in the vein. The mineral also occurs as anhedral crystals in direct contact with johnbaumite. In the cahnite crystals, the johnbaumite are partly included as inclusions. Figure 1 shows a photomicrograph of cahnite from Fuka.

\section{Physical and optical properties}

Cahnite is white and transparent with a vitreous luster in hand specimen. Optically, the mineral is uniaxial negative with refractive indices $\omega=1.658(1)$ and $\varepsilon=$ 1.657(1). The mineral has a characteristic anomalous interference color due to the very low birefringence and
Table 1. Optical and physical properties of cahnite

\begin{tabular}{|c|c|c|c|}
\hline & 1 & 2 & 3 \\
\hline$\omega$ & 1.658 & 1.662 & 1.655 \\
\hline$\varepsilon$ & 1.657 & 1.663 & 1.656 \\
\hline Sign & uniaxial (-) & uniaxial $(+)$ & uniaxial (+) \\
\hline $\mathrm{D}\left(\mathrm{g} / \mathrm{cm}^{3}\right)$ & $3.13(2)$ & 3.156 & 3.06 \\
\hline $\mathrm{VHN}_{10}$ & $413\left(\mathrm{~kg} / \mathrm{mm}^{2}\right)$ & - & - \\
\hline MHN & 4.5 & 3 & - \\
\hline Luster & vitreous & vitreous & vitreous \\
\hline Color & $\begin{array}{l}\text { colorless } \\
\text { white }\end{array}$ & $\begin{array}{l}\text { colorless } \\
\text { white }\end{array}$ & colorless \\
\hline
\end{tabular}

1. Fuka, Okayama Prefecture, Japan. This study.

2. Franklin, New Jersey (Palache and Bauer, 1927).

3. Siberian deposit (Malinko, 1966).

considerable dispersion. The Vickers microhardness is $413 \mathrm{~kg} \mathrm{~mm}^{-2}$ (10 g load) and the Moh's hardness number is 4.5 . The density measured by heavy liquid is $3.13(2) \mathrm{g} \mathrm{cm}^{-3}$. In Table 1, the optical and physical properties are compared with those reported by Palache and Bauer (1927) and Malinko (1966). Cahnite from Fuka shows an intermediate value for the refractive indices, and an opposite sign compared with the earlier reports. Although the hardness is higher than that of the type locality (Palache and Bauer, 1927), the density shows a close resemblance.

Under short wavelength ultraviolet excitation, cahnite from Fuka emits yellow luminescence at room temperature. The infrared absorption spectrum of the mineral was measured by the $\mathrm{KBr}$ method for the region 4000 to $250 \mathrm{~cm}^{-1}$, as shown in Figure 2. The absorption bands at 3400 to $3170 \mathrm{~cm}^{-1}$ are attributed to $\mathrm{OH}$

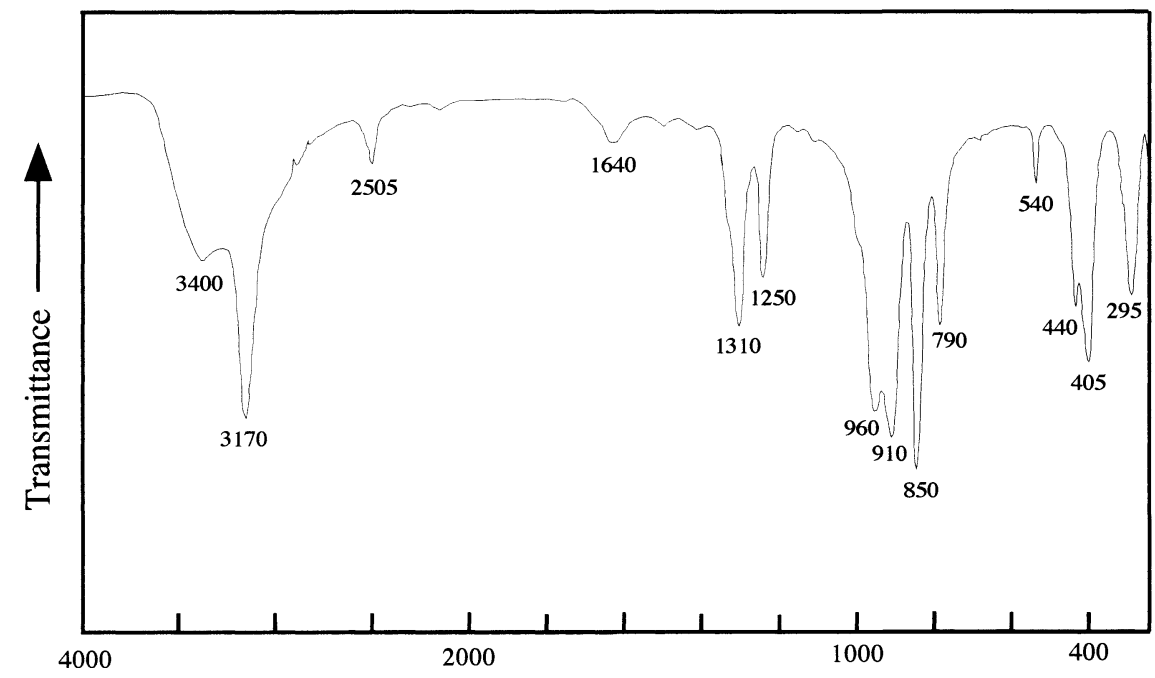

Wave number $\left(\mathrm{cm}^{-1}\right)$

Figure 2. Infrared absorption spectrum of cahnite from Fuka. 
Table 2. X-ray powder diffraction data for cahnite

\begin{tabular}{|c|c|c|c|c|c|}
\hline \multicolumn{4}{|c|}{1} & \multicolumn{2}{|c|}{2} \\
\hline h k 1 & $\mathrm{~d}($ calc $)$ & $\mathrm{d}$ (meas) & I & $\mathrm{d}$ & $\mathrm{I}$ \\
\hline 110 & 5.02 & 5.04 & 16 & 5.02 & 20 \\
\hline 101 & 4.67 & 4.68 & 10 & 4.67 & 20 \\
\hline 200 & 3.55 & 3.56 & 100 & 3.56 & 100 \\
\hline 002 & & & & 3.10 & 2 \\
\hline 211 & 2.826 & 2.827 & 10 & 2.833 & 19 \\
\hline 112 & 2.635 & 2.636 & 16 & 2.640 & 48 \\
\hline 220 & 2.511 & 2.512 & 8 & 2.514 & 15 \\
\hline 202 & 2.333 & 2.334 & 6 & 2.336 & 17 \\
\hline $\begin{array}{lll}3 & 1 & 0\end{array}$ & 2.246 & 2.247 & 12 & 2.249 & 13 \\
\hline $\begin{array}{lll}3 & 0 & 1\end{array}$ & 2.211 & 2.212 & 8 & 2.215 & 15 \\
\hline 103 & 1.982 & 1.981 & 2 & 1.986 & 4 \\
\hline 222 & 1.950 & 1.950 & 2 & 1.951 & 5 \\
\hline 321 & 1.877 & 1.877 & 4 & 1.879 & 10 \\
\hline 312 & 1.818 & 1.817 & 18 & 1.818 & 52 \\
\hline 400 & 1.775 & 1.776 & 6 & 1.777 & 10 \\
\hline 213 & 1.731 & 1.731 & 2 & 1.733 & 3 \\
\hline 330 & 1.674 & 1.674 & 2 & 1.676 & 1 \\
\hline 411 & 1.659 & 1.659 & 2 & 1.660 & 5 \\
\hline 420 & 1.588 & 1.587 & 6 & 1.590 & 10 \\
\hline 303 & 1.556 & 1.556 & 2 & 1.558 & 2 \\
\hline $\mathbf{a}(\AA)$ & & $7.101(1)$ & & 7.095( & \\
\hline c $(\AA)$ & & $6.192(1)$ & & 6.190 & \\
\hline
\end{tabular}

1. Fuka, Okayama Prefecture, Japan. This study.

2. Franklin, New Jersey (Embrey, 1960). stretching vibrations. Numerous bands observed at 1310 to $790 \mathrm{~cm}^{-1}$ are characteristic of borates, and bands at around $400 \mathrm{~cm}^{-1}$ are characteristic of arsenates.

\section{X-ray study}

The X-ray powder diffraction data for cahnite from Fuka was obtained by an X-ray diffractometer (Rigaku RINT-2500V) with graphite-monochromatized $\mathrm{Cu}^{-}$ $\mathrm{K} \alpha_{1}$ radiation generated at $40 \mathrm{kV}$ and $200 \mathrm{~mA}$. The reflections were indexed on the tetragonal cell reported by Embrey (1960). The cell parameters calculated from the powder data are $a=7.101(1)$ and $c=6.192(1) \AA$. The data are in close agreement with those reported by Embrey (Table 2).

\section{Thermal behavior}

DTA and TG curves were obtained by heating $8.7 \mathrm{mg}$ of the sample from room temperature to $900^{\circ} \mathrm{C}$ at a rate of $10^{\circ} \mathrm{C} \mathrm{min}^{-1}$ (Rigaku TG-8120), as shown in Figure 3. The DTA curve has a strong endothermic peak at $437^{\circ} \mathrm{C}$, corresponding to the loss of water, and weak exothermic peaks at 674 and $766^{\circ} \mathrm{C}$. The thermal behavior is similar to that reported by Malinko (1966).

\section{Chemical composition}

Chemical analysis using an electron microprobe analyzer (WDS) revealed the presence of $\mathrm{Ca}, \mathrm{As}, \mathrm{B}$ and $\mathrm{Si}$,

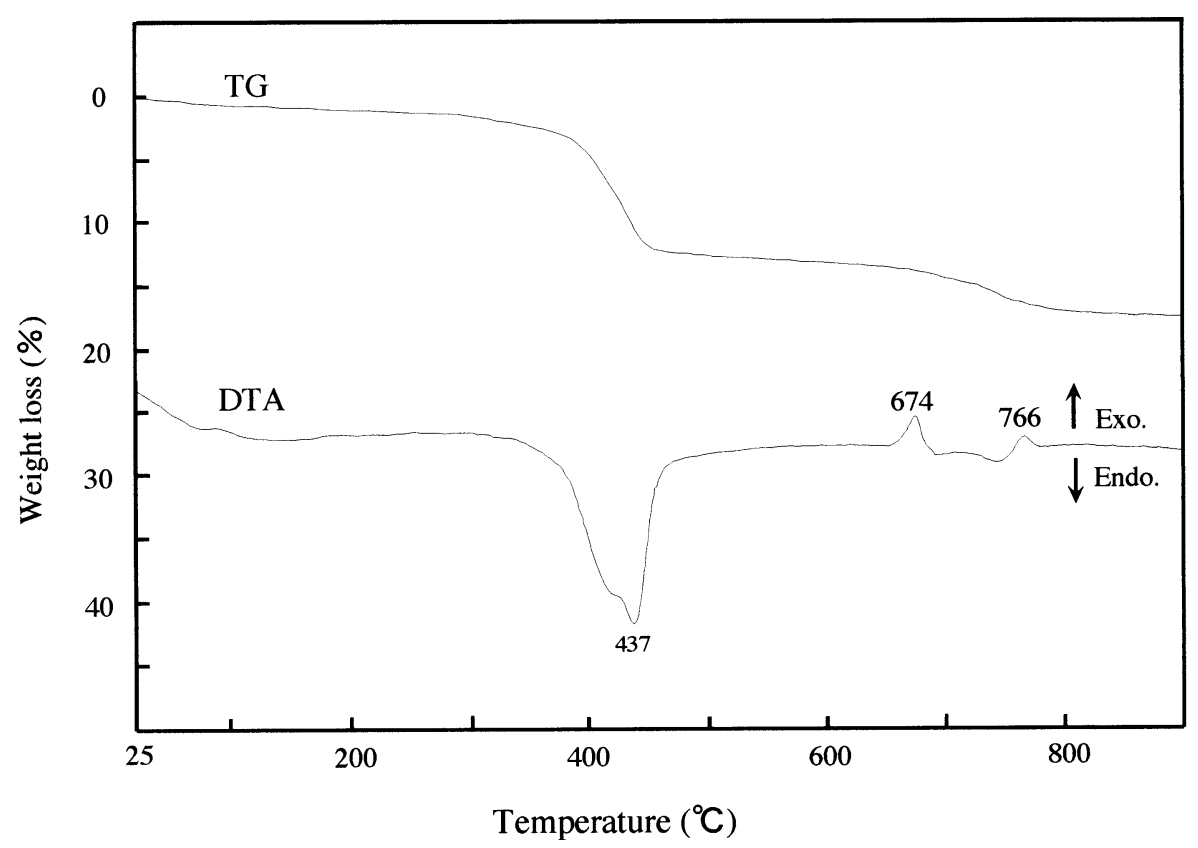

Figure 3. DTA and TG curves of cahnite from Fuka. 
Table 3. Chemical composition of cahnite

\begin{tabular}{|c|c|c|c|}
\hline & 1 & 2 & 3 \\
\hline \multicolumn{4}{|c|}{ Weight percentage } \\
\hline $\mathrm{B}_{2} \mathrm{O}_{3}$ & $10.92 *$ & 11.86 & 11.74 \\
\hline $\mathrm{CaO}$ & 38.63 & 37.62 & 37.64 \\
\hline $\mathrm{As}_{2} \mathrm{O}_{5}$ & 35.43 & 38.05 & 38.54 \\
\hline $\mathrm{SiO}_{2}$ & 1.15 & - & - \\
\hline $\mathrm{H}_{2} \mathrm{O}$ & $12.15^{* *}$ & 12.42 & 12.08 \\
\hline Total & 98.28 & 99.95 & 100 \\
\hline \multicolumn{4}{|c|}{ Mole ratio (basis: $\mathrm{O}=8$ ) } \\
\hline $\mathrm{B}$ & 0.95 & 1.01 & 1 \\
\hline $\mathrm{Ca}$ & 2.09 & 1.99 & 2 \\
\hline As & 0.93 & 0.98 & 1 \\
\hline $\mathrm{Si}$ & 0.06 & - & - \\
\hline $\mathrm{H}$ & 4.08 & 4.09 & 4 \\
\hline
\end{tabular}

1. Fuka, Okayama Prefecture, Japan. This study.

2. Franklin, New Jersey (Palache and Bauer, 1927).

3. Theoretical values of $\mathrm{Ca}_{2} \mathrm{BAsO}_{4}(\mathrm{OH})_{4}$.

*: ICP-MS, **: TG.

except for $\mathrm{Li}$ and $\mathrm{Be}$. The $\mathrm{B}$ content was determined by an ICP-MS (Seiko SPQ-8000H). Before analysis, the sample was dissolved in dilute hydrochloric acid, and B was separated from the other elements using an ion -exchange column with an Amberlite CG-120 strong cation-exchange resin. The concentrations of $\mathrm{Ca}, \mathrm{Si}$ and As were measured by the electron microprobe analyzer (JEOL JSM-5410LV+JED-2140). The $\mathrm{H}_{2} \mathrm{O}$ content was obtained by the weight loss of the sample between 110 to $560^{\circ} \mathrm{C}$ in the TG curve. The results are given in Table 3, and are compared with the theoretical values calculated from the ideal formula of $\mathrm{Ca}_{2} \mathrm{BAsO}_{4}(\mathrm{OH})_{4}$, and those reported by Palache and Bauer (1927). The empirical formula of cahnite from Fuka is $\mathrm{Ca}_{2.09} \mathrm{~B}_{0.95} \mathrm{As}_{0.93} \mathrm{Si}_{0.06} \mathrm{O}_{3.92}(\mathrm{OH})_{4.08}$ on the basis of $\mathrm{O}=8$. The chemical composition of cahnite from Fuka is very close to those of the ideal formula and the type locality.

\section{Discussion}

Malinko (1966) reported that cahnite at the Siberian deposit was formed as a product of a late epithermal stage of the hydrothermal process. Malinko also described that boron was added through hydrothermal solutions in this stage, and arsenic may have come from the dissociation of the more hypothermal arsenate, svabite $\mathrm{Ca}_{5}\left(\mathrm{AsO}_{4}\right)_{3} \mathrm{~F}$. On the other hand, Helvac1 (1984) reported that cahnite at the Emet borate deposits was formed by the transformation of colemanite, $\mathrm{Ca}_{2} \mathrm{~B}_{6} \mathrm{O}_{11} \cdot 5 \mathrm{H}_{2} \mathrm{O}$, or as a result of dehydration of teruggite, $\mathrm{Ca}_{4} \mathrm{MgAs}_{2} \mathrm{~B}_{12} \mathrm{O}_{22}(\mathrm{OH})_{12} \cdot 12 \mathrm{H}_{2} \mathrm{O}$.

At the Fuka mine, cahnite crystals occur in direct contact with johnbaumite, $\mathrm{Ca}_{5}\left(\mathrm{AsO}_{4}\right)_{3}(\mathrm{OH})$, and also include the small size of the johnbaumite. From the mode of the occurrence, it is likely that cahnite at the Fuka mine was formed as a secondary mineral by hydrothermal alteration of johnbaumite. The boron required for the formation of cahnite appears to have been added through a late-hydrothermal solution. The occurrence of cahnite at Fuka is similar to that reported by Malinko (1966), though the associated mineral species is different.

\section{Acknowledgements}

We would like thank Mr. M. Shimada and Mr. S. Kishi for field work conducted, and Mr. L. Anthony of Okayama University of Science for proofreading the final manuscript.

\section{References}

Bugge, J.A.W. (1951) Minerals from the skarn iron ore deposits at Arendal, Norway. I. Cahnite from the Klodeborg mine. Det Kongelige Norske Videnskabers Selskab Forhandlinger, 24, 79-81.

Embrey, P.G. (1960) Cahnite from Capo di Bove, Rome. Mineralogical Magazine, 32, 666-668.

Helvac1, C. (1984) Occurrence of rare borate minerals: Veatchite- A, tunellite, teruggite and cahnite in the Emet borate deposits, Turkey. Mineralium Deposita, 19, 217-226.

Kusachi, I., Henmi, C. and Kobayashi, S. (1996) Johnbaumite from Fuka, Okayama Prefecture, Japan. Mineralogical Journal, 18, 60-66.

Malinko, S.V. (1966) First find of cahnite in the USSR. Doklady of the Academy of Science of the USSR, Earth Science Sections. 117-120. Translated from Doklady Akademii Nauk SSSR, 1966, 166, 695-697.

Palache, C. and Bauer, L.H. (1927) Cahnite, a new boroarsenate of calcium from Franklin, New Jersey. American Mineralogist, 12, 149-153.

Manuscript received; 25 October, 2001

Manuscript accepted; 19 February, 2002 